\title{
Effect of fertilization on below-ground plant mass of submontane Polygono-Cirsietum meadow
}

\section{P. Holub ${ }^{1}$, I. Tůma ${ }^{2}$, K. Fiala ${ }^{3}$}

1) Mgr. Petr Holub, PhD., Global Change Research Centre, Academy of Sciences of the Czech Republic, Bëlidla 4a, Brno CZ-603 00, Czech Republic, tel: +420 511192 270, e-mail: holub.p@czechglobe.cz

${ }^{2)}$ Ing. Ivan Tưma, PhD., Department of Agrochemistry, Soil Science, Microbiology and Plant Nutrition, Faculty of Agronomy, Mendel University in Brno, Zemédélská 1, CZ-613 00 Brno, Czech Republic, tel: +420 545133 396, e-mail:tuma@mendelu.cz

${ }^{3 *}$ RNDr. Karel Fiala, CSc., Department of Vegetation Ecology, Institute of Botany, Academy of Sciences of the Czech Republic, Lidická 25, CZ-602 00 Brno, Czech Republic, tel: +420 541126 225, e-mail:karel.fiala@ ibot.cas.cz

Abstract: Holub, P., Tůma, I., Fiala, K. 2013: Effect of fertilization on below-ground plant biomass of submontane Polygono-Cirsietum meadow. - Beskydy, 6 (1): 33-42

\begin{abstract}
We assessed below-ground net primary productivity (BNPP) in the wet submontane Cirsium meadow occurred in the highland region of the Czech Republic. Effect of four different fertilization levels on BNPP was estimated in 1992. At the beginning of the growing season (April 29), total dry mass of rhizomes, roots and total below-ground plant parts of unfertilized stand reached 177, 1478 and 1657 g.m.-2, respectively. Their living parts formed $42 \%$ of their total dry mass. In comparison with unfertilized stands, however, the greatest accumulation of dry mass of rhizomes (504 g.m ${ }^{-2}$ ), roots (1503 g.m ${ }^{-2}$ ) and total below-ground dry mass (2008 g.m ${ }^{-2}$ ) was reached after application of $90 \mathrm{kgN} \cdot \mathrm{ha}^{-1}$. Similarly, the highest BNPP values for living (435 g. $\left.\mathrm{m}^{-2} \cdot \mathrm{yr}^{-1}\right)$ and total below-ground dry mass ( $351 \mathrm{~g} \cdot \mathrm{m}^{-2} \cdot \mathrm{yr}^{-1}$ ) were calculated for the stand affected by the same amount of fertilization. These data show how variable role grasslands can play in accumulation and turn over of root biomass due to different levels of fertilization.
\end{abstract}

Keywords: biomass partitioning, grassland, fertilization, primary productivity

\section{Introduction}

Root mass and rhizosphere represent the main pool of organic matter and geobioelements of grassland ecosystems. Concretely 60 to $90 \%$ of net primary production (below-ground plant parts) and $90 \%$ of secondary production (microorganisms and soil animals) was found in soil of grassland ecosystems (see Stanton 1988). Likewise Hui and Jackson (2005) estimated broader range of root primary production (40 to $87 \%$ of total production) in grassland ecosystems occurring at the large geographical and temperate scales. Decomposing dead roots enrich soil by organic matter and influence substantially soil quality. These processes are particularly important and are considered as one of main feature of grasslands (Rychnovská 1983). It is also important to understand how habitat quality affects soil carbon $(\mathrm{C})$ pools/fluxes, particularly, as these ecosystems store up to $30 \%$ of the world below-ground C (see Risch et al. 2007).

Summaries of the observations of various authors (e.g. Velich 1986, Gáborčík, Kohoutek 1999, Fiala 2010) shows that increasing intensity of fertilization (above all nitrogen) decrease root relative to shoot growth. Nevertheless these summarized data also showed on contradictory results concerning root biomass production affected by fertilization. Cutting and grazing increased mortality of roots which resulted in 
decomposition and decrease of the amount of dry mass of roots (e.g. Tesařová 1993, Fiala 1997, Risch et al. 2007).

The main aim of our study was to estimate the effect of various managements (fertilization, cutting) on accumulation of the total belowground dry matter (TBDM) in different part of the growing season and calculate BNPP in the first year of the experiment. We hypothesized that:

(1) The effect of fertilization will be manifested in a greater accumulation of TBDM, above all living below-ground organs, because applied fertilization can increase decomposition of dead plant parts. However the highest accumulation of TBDM will be not connected with the highest intensity of fertilization.

(2) We will find a positive effect of fertilization on BNPP, but we will estimate a lower BNPP at the highest (the fourth) level of fertilization.

\section{Material and methods}

\section{Study site}

Amounts of total below-ground dry mass (TBDM) were estimated for the meadow stand in the Ždárské vrchy landscape reserve in the Moravian-Bohemian Highland. This area is, from the phytogeographic point of view, a part of Hercynicum (region build of granite and crystalic rocks with Ca-deficient soil). Experimental stands were located near the village of Kameničky $\left(49^{\circ} 43^{\prime} \mathrm{N}, 15^{\circ} 58^{\prime} \mathrm{E}\right.$, altitude $530 \mathrm{~m}$ a.s.l.). The mean annual temperature and sum of precipitation (for the period 1961-1990) in the region was $7^{\circ} \mathrm{C}$ and $762 \mathrm{~mm}$ (Kameničky, Svratouch). Haplic Stagnosol Dystric soil occurred (see IUSS Working Group WRB 2006) and soil nutrient content was lower. More detailed description of the area, plant community and its habitats are given by Balátová-Tuláčková et al. (1977) and Hrabě et al. (2002).

The comparison of the amount of actual precipitation and air temperature for the long-term average values (1961-1990), recorded for the region of the Moravian-Bohemian Highland, indicates that growing season 1992 was drier and warmer according to data published by the Czech Hydrometeorological Institute (Fig. 1). In 1992, sum of the precipitation was about $13 \%$ below the long-term averages and air temperature was higher by $0.9^{\circ} \mathrm{C}$ in the average. Studied grassland was also influenced by a higher underground water table, ranging about $-20 \mathrm{~cm}$ below soil surface due to the melting of a huge amount of snow. However, in summer months, underground water table decreased here often down to $-50 \mathrm{~cm}$.

The studied grassland (Polygono-Cirsietum palustris, Balátová-Tuláčková et al. 1977) was characterized as a species rich stand of wet meadow. The species composition of the stand was characterized by more frequent species such as Cirsium palustre, Deschampsia caespitosa, Agrostis capillaris, A. canina, Anthoxanthum odoratum, Polygonum bistorta, Sanguisorba officinalis and others. Effects of mowing (three times per year) and NPK fertilization on production of below-ground plant parts on four nutrient levels (treatment 1 - unfertilized stand, treatment 2-30 kg.ha- ${ }^{-1}$ of $\mathrm{P}, 60 \mathrm{~kg} \cdot \mathrm{ha}^{-1}$ of $\mathrm{K}$, treatment 3-90 kg.ha-1 of N, $30 \mathrm{~kg} \cdot \mathrm{ha}^{-1}$ of $\mathrm{P}, 60 \mathrm{~kg} \cdot \mathrm{ha}^{-1}$ of $\mathrm{K}$, treatment $4-180 \mathrm{~kg} \cdot \mathrm{ha}^{-1}$ of N, $30 \mathrm{~kg} \cdot \mathrm{ha}^{-1}$ of $\mathrm{P}$, $60 \mathrm{~kg} \cdot \mathrm{ha}^{-1}$ of K) were examined (see Hrabě et al. 2002). Five replications of each treatment were in Latin square design. In the same stands (NO, N0-PK, N90-PK and N180-PK) the long-term average of above-ground biomass reached 443, 607, 728 and 860 g.m- ${ }^{-2}$, respectively (Hrabě et al. 2002).

\section{Below-ground plant parts analyses}

To make quantitative determination of the initial values of the below-ground plant matter (recorded on April 29, before start of fertilization experiment) soil cores ( $5 \mathrm{~cm}$ in diameter, $12 \mathrm{~cm}$ depth, $n=20$ ) were collected. Subsequently, the soil cores were taken before the first cutting (June 28) and in autumn (November 4). Three additional soil cores $(2 \mathrm{~cm}$ in diameter) were taken in order to estimate the amount of living and dead roots. Collected samples were washed in nylon bags and on sieves of $0.5 \mathrm{~mm}$ mesh size, and dried at $70-80{ }^{\circ} \mathrm{C}$ to the constant mass. The method developed by Ward et al. (1978) and modified by Tesařová et al. (1982) was used to determine living and dead root biomass. For this purpose, the Congo-red staining technique was applied. After washing of larger soil cores, all samples were visually separated into total roots, living and dead rhizomes and underground shoot bases according to their colour and mechanical consistency. These figures are referred to as rhizome values. Data on dry mass of living and dead roots and rhizomes were then use to estimate both the percentage proportion and the amount of living and dead roots and rhizomes per $\mathrm{m}^{2}$. The summing of positive increases in below-ground dry mass were calculated (BNPP), i.e. maximum value minus minimum value recorded in the growing season. 


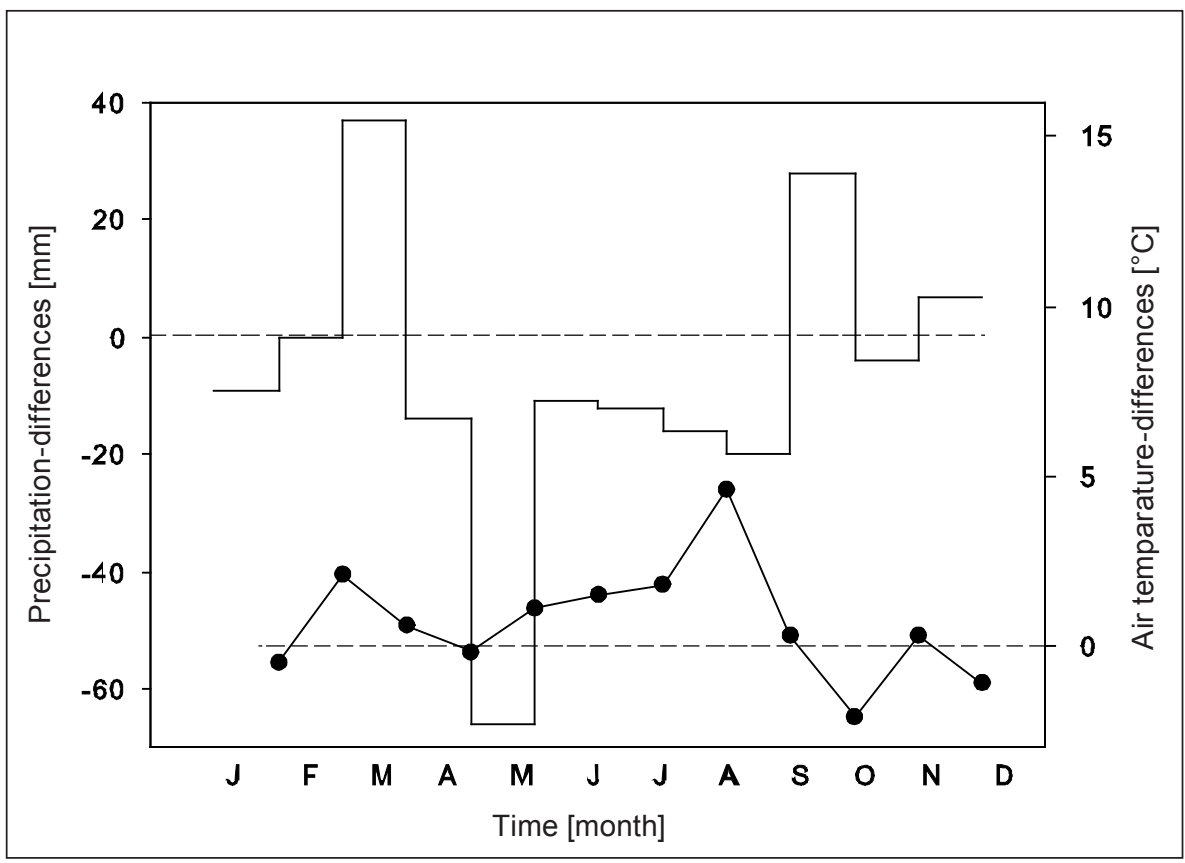

Fig. 1: Differences in the amount of precipitation (lines) and air temperature (black circles) from the long-term average values (1961-1990) recorded from studied region in 1992 (according to data published by the Czech Hydrometeorological Institute).

\section{Statistical analysis}

Obtained data were evaluated by means of the multifactorial analysis of variance, using the statistical package STATISTICA 7.0. A t-test was performed to compare mean differences between unfertilized and fertilized treatments. Two-way ANOVA analysis was used to test the effect of time period and fertilization as independent variables on the below-ground biomass parameters as dependent variables. F-value and resulting P level were determined. Transformation of the data was not necessary.

\section{Results and discussion}

\section{Below-ground plant dry mass}

The ANOVA analysis has shown that nearly all living fractions (living rhizome, roots and total living below-ground dry mass) were not significantly affected by period of the year and intensity of fertilization of the studied grassland (Tab. 1). However, amount of dead roots and total below-ground dry mass were affected significantly by period, fertilization and interactions of period and fertilization. Total dry mass of rhizomes, roots and total below-ground plant parts of unfertilized stand represented 177, 1478 and
$1657 \mathrm{~g} \cdot \mathrm{m}^{-2}$, respectively, at the beginning of the growing season (April 29). Their living parts formed $41.8,41.6$ and $41.6 \%$ of their total dry mass, respectively (Tab. 2). In June, proportion of living parts was rather variable, however increasing fertilization resulted in the lower values of living and dead below-ground ratios (Fig. 2).

Results obtained from previous observations in different types of grasslands (see Fiala 1997, 2010) generally shown, that the highest TBDM was recorded in wet meadows, varying mostly from 2 to $4 \mathrm{~kg} . \mathrm{m}^{-2}$. Our presented data (1722-1786 g.m $\mathrm{m}^{-2}$ ) fall into a lower part of mentioned range of values. Nevertheless, these data confirmed our first assumption that studied wet unfertilized submontane Cirsium meadow can reached relatively high amount of TBDM. TBDM can usually increase with strongly increasing moisture and dryness of the sites. Therefore TBDM can be higher under conditions with reduced rate of decomposition processes and resulted in an increase of amount of undecomposed dead plant matter (Fiala 2010).

The highest amount of living roots was recorded around the middle of the soil moisture gradient (Fiala 1990). In the present study, the percentage of living roots (41.6 to $58.5 \%$ ) in total root dry mass of unfertilized studied meadow 


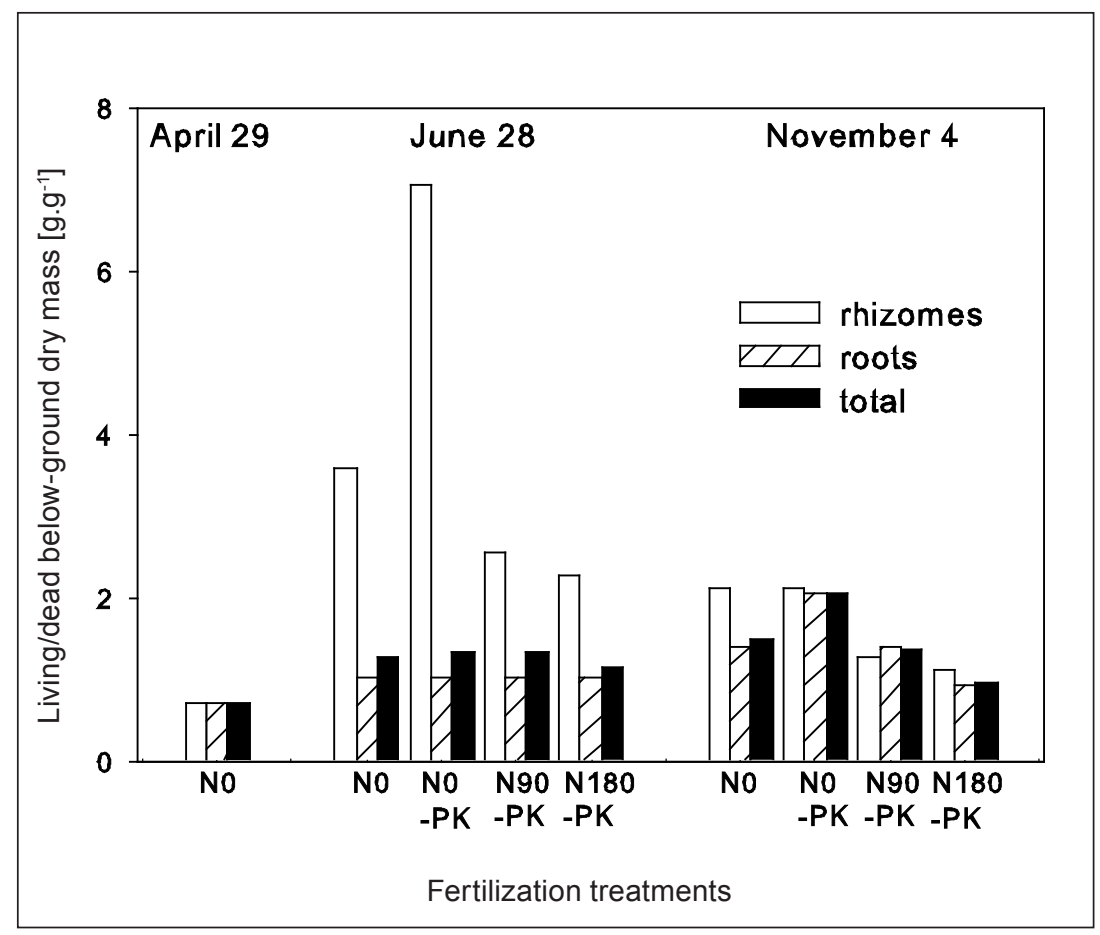

Fig. 2: Ratio between living and dead below-ground dry mass in different fertilization treatments in wet submontane Cirsium meadow recorded during the growing season 1992.

stands fall also in the central part of meadow moisture gradient occurring in studied region (60 to $90 \%$ ). These data were in accordance with previously analyzed root samples from the region of the Moravian-Bohemian Highland (Fiala 1990, 1997). These findings were also supported by our lower root values gathered previously in warmer and drier region of the southern Moravia (e.g. Pilát 1969, Jakrlová 1971, Fiala 2001, Fiala et al. 2004).

Mowing usually resulted in a decrease of root biomass; however, the response of belowground plant biomass does not follow the same tendency in all communities (see summary published by Fiala 1997). He has found that plant communities occurring in studied region and rich in plant species and mostly with high amount of living below-ground biomass were more resistant to mowing. The studied meadow belongs to the same type of plant communities.

\section{Below-ground production}

Obtained values of dry mass of below-ground plant parts of studied meadow stand, recorded during the growing season, enable us to estimate below-ground net primary productivity (BNPP). The values, calculated as maximum minus minimum values, indicated that in the course of the growing season, the largest amount of root mass was produced in stands affected by the third fertilization level (N90-PK), i.e. 351 or $435 \mathrm{~g} . \mathrm{m}^{-2} . \mathrm{yr}^{-1}$, calculated on the base of total or living below-ground dry mass, respectively (Tab. 3). Calculated data on turn-over rate of below-ground dry mass of studied meadow, estimated as the ratio of BNPP (assessed from increments of living biomass) related to the recorded maximum of below-ground dry mass, varied from 0.14 to 0.22 (about $14-22 \%$ of TBDM was renovated annually). The fastest turn-over rate was found in stands where the third intensity of fertilization (N90-PK) was introduced (Tab. 3).

Most authors reported that estimates of the BNPP from the dynamic of root pattern can result in erroneous estimates (e.g. Sing et al. 1984, Vogt et al. 1986, Lauenroth et al. 2006, Milchunas 2009). Nevertheless, we try to estimate BNPP in the similar way. Above all data on living below-ground plant parts (LBDM) recorded in 1992 enables us to calculate their increments (maximum LBDM minus minimum LBDM). We assessed approximately 316 g.m $\mathrm{m}^{-2}$ of BNPP recorded during time period from April 29 to June 28 in unfertilized stand. This value fall into the 
Tab. 1: The effect of fertilization and period on the amount of dry matter of different below-ground plant parts (in g. $\left.m^{-2}\right)$ in wet submontane Cirsium meadow: results of two-way ANOVA analysis

(NS: not significant, ${ }^{*} P<0.05,{ }^{* *} P<0.01$, ${ }^{* *} P<<0.001$ ).

\begin{tabular}{|c|c|c|c|c|c|c|c|}
\hline \multicolumn{8}{|c|}{ Two-way ANOVA (F - test) } \\
\hline \multirow[b]{2}{*}{ Effects } & \multirow[b]{2}{*}{$d f$} & \multicolumn{2}{|c|}{ Rhizome live } & \multicolumn{2}{|c|}{ Rhizome dead } & \multicolumn{2}{|c|}{ Rhizome total } \\
\hline & & $F$ & $P$ & $F$ & $P$ & $F$ & $P$ \\
\hline Period (P) & 1 & 1.3 & NS & 4.3 & $*$ & 0.1 & NS \\
\hline Fertilization (F) & 3 & 1.0 & NS & 1.2 & NS & 0.9 & NS \\
\hline \multirow[t]{3}{*}{$\mathbf{P} \times \mathbf{F}$} & 3 & 0.5 & NS & 0.3 & NS & 0.7 & NS \\
\hline & & \multicolumn{2}{|c|}{ Root live } & \multicolumn{2}{|c|}{ Root dead } & \multicolumn{2}{|c|}{ Root total } \\
\hline & $d f$ & $F$ & $P$ & $F$ & $P$ & $F$ & $P$ \\
\hline Period (P) & 1 & 1.2 & NS & 45.5 & $* * *$ & 6.4 & $*$ \\
\hline Fertilization (F) & 3 & 2.3 & NS & 19.7 & $* * *$ & 6.0 & $* * *$ \\
\hline \multirow[t]{3}{*}{$\mathbf{P} \times \mathbf{F}$} & 3 & 3.0 & * & 5.2 & $* *$ & 0.1 & NS \\
\hline & & \multicolumn{2}{|c|}{ Below-ground live } & \multicolumn{2}{|c|}{ Below-ground dead } & \multicolumn{2}{|c|}{ Below-ground total } \\
\hline & $d f$ & $F$ & $P$ & $F$ & $P$ & $F$ & $P$ \\
\hline Period (P) & 1 & 0.3 & NS & 11.0 & $* *$ & 3.2 & NS \\
\hline Fertilization (F) & 3 & 1.9 & NS & 12.1 & $* * *$ & 2.7 & $*$ \\
\hline \multirow[t]{3}{*}{$\mathbf{P} \times \mathbf{F}$} & 3 & 1.2 & NS & 2.8 & $*$ & 0.5 & NS \\
\hline & \multicolumn{3}{|c|}{ Detritus } & & & & \\
\hline & $d f$ & $F$ & $P$ & & & & \\
\hline Period (P) & 1 & 33.8 & $* * *$ & & & & \\
\hline Fertilization (F) & 3 & 26.8 & $* * *$ & & & & \\
\hline $\mathbf{P} \times \mathbf{F}$ & 3 & 9.8 & $* * *$ & & & & \\
\hline
\end{tabular}

lower part of the data range found in the similar type of grasslands, since both Rychnovská (1993) and Hui and Jackson (2005), whose summarized data of large collection of field measurements, concluded that BNPP of temperate seminatural grasslands of Eurasia and from savannas to cold desert steppe varied in a large scale of values (230-1370 and 240-2147 g.m-2. $\mathrm{yr}^{-1}$ ), respectively. But humid temperate and wet meadows had intermediate mean values. Therefore obtained values are necessary to evaluate with caution. The second period of the root growth (June 28 to November 4) may be influenced by an increase of root mortality due to the effect of mowing and dry summer months (Hayes, Seastedt 1987, Pielota, Smucker 1995, Frank 2007, Wedderburn et al. 2010, Fiala et al. 2012). As temperature decrease and precipitation increase, plants may allocate relatively more below-ground (Gill et al. 2002, Ni 2004, Yahdjian, Sala 2006, Fiala et al. 2012).

Data on turn-over rate values recorded over the whole world were reviewed by Gill and Jackson (2000). They reported that mean annual turn-over rate for roots of grasses was 55\% and concluded that there is a strong positive exponential relationship between root turn-over rate in grasslands and the mean annual temperature. Thus recorded relatively large amount of dead below-ground dry mass and soil detritus can be associated with wet soil conditions of the Cirsium community growing in cooler highland and resulting in slower root turnover in the present study.

The fastest growth of below-ground plant parts can occur in different parts of growing season reflecting the annual cycle of vegetative activity (Titlyanova et al. 1999). Our findings confirmed results of several authors that seasonal periodicity and higher percentage of active roots were usually characterized by two peaks. One peak was at the beginning or in the middle of summer (after flowering) and the second, lowest, in autumn (e.g. Speidel 1976, Cheng et al. 1990, Pandey, Singh 1992, Titlyanova et al. 1997, Fiala 2010). On the other side, mid-growing season drought can result in accelerated death and decomposition of new roots (Gross et al. 1993). The reduction of root growth due to lower precipitation has been published 
Tab. 2: Mean values of the amount of dry matter of different below-ground plant parts (in g. $^{-2}$ ) in wet submontane Cirsium meadow recorded during the growing season 1992. Different letters between fertilization treatments denote significantly different values for individual biomass parameter (Tukey HSD test $(P<0.05)$ after ANOVA).

\begin{tabular}{|c|c|c|c|c|}
\hline Fertilization & No & N0-PK & N90-PK & N180-PK \\
\hline \multicolumn{5}{|l|}{ Date of harvest } \\
\hline \multicolumn{5}{|l|}{ April 29, 1992} \\
\hline Living rhizomes & $74 \pm 48$ & - & - & - \\
\hline Dead rhizomes & $103 \pm 48$ & & & \\
\hline Total rhizomes & $177 \pm 86$ & - & - & - \\
\hline Living roots & $615 \pm 72$ & - & - & - \\
\hline Dead roots & $863 \pm 110$ & - & - & - \\
\hline Total roots & $1478 \pm 172$ & - & - & - \\
\hline Living below-ground & $689 \pm 98$ & - & - & - \\
\hline Dead below-ground & $968 \pm 131$ & - & - & - \\
\hline Total below-ground & $1657 \pm 225$ & - & - & - \\
\hline Soil detritus & $93 \pm 11$ & - & - & - \\
\hline \multicolumn{5}{|l|}{ June 28, 1992} \\
\hline Living rhizomes & $284 \mathrm{ab}$ & $278 \mathrm{ab}$ & $363 \mathrm{~b}$ & $192 \mathrm{ab}$ \\
\hline Dead rhizomes & $78 \mathrm{ab}$ & $68 \mathrm{a}$ & $142 \mathrm{ab}$ & $85 \mathrm{ab}$ \\
\hline Total rhizomes & $362 \mathrm{a}$ & $346 a$ & $504 \mathrm{a}$ & $277 \mathrm{a}$ \\
\hline Living roots & $721 \mathrm{abc}$ & $639 a$ & $761 \mathrm{bc}$ & $756 \mathrm{bc}$ \\
\hline Dead roots & $703 \mathrm{~cd}$ & $626 \mathrm{bc}$ & $742 \mathrm{~d}$ & $737 d$ \\
\hline Total roots & $1424 \mathrm{bc}$ & $1265 \mathrm{ab}$ & $1503 \mathrm{c}$ & $1493 \mathrm{c}$ \\
\hline Living below-ground & $1005 \mathrm{ab}$ & $917 a b$ & $1124 \mathrm{~b}$ & $948 \mathrm{ab}$ \\
\hline Dead below-ground & $781 \mathrm{bcd}$ & $693 \mathrm{~b}$ & $884 d$ & $822 \mathrm{~cd}$ \\
\hline Total below-ground & $1786 \mathrm{ab}$ & $1610 \mathrm{a}$ & $2008 \mathrm{~b}$ & $1770 \mathrm{ab}$ \\
\hline Soil detritus & $226 \mathrm{~cd}$ & $200 \mathrm{bc}$ & $239 d$ & $237 d$ \\
\hline \multicolumn{5}{|l|}{ November 4, 1992} \\
\hline Living rhizomes & $263 \mathrm{ab}$ & $272 \mathrm{ab}$ & $193 \mathrm{ab}$ & $156 \mathrm{a}$ \\
\hline Dead rhizomes & $125 \mathrm{ab}$ & $128 \mathrm{ab}$ & $153 \mathrm{~b}$ & $141 \mathrm{ab}$ \\
\hline Total rhizomes & $388 \mathrm{a}$ & $400 \mathrm{a}$ & $346 a$ & $296 \mathrm{a}$ \\
\hline Living roots & $782 \mathrm{c}$ & $752 \mathrm{bc}$ & $796 \mathrm{c}$ & 66lab \\
\hline Dead roots & $553 \mathrm{~b}$ & $369 a$ & $573 \mathrm{~b}$ & $723 d$ \\
\hline Total roots & $1335 \mathrm{bc}$ & $1121 \mathrm{a}$ & $1369 \mathrm{bc}$ & $1384 \mathrm{bc}$ \\
\hline Living below-ground & $1044 b$ & $1023 \mathrm{ab}$ & $989 a b$ & $817 a$ \\
\hline Dead below-ground & $678 \mathrm{~b}$ & $497 \mathrm{a}$ & $727 \mathrm{bc}$ & $863 \mathrm{~d}$ \\
\hline Total below-ground & $1722 \mathrm{ab}$ & $1520 \mathrm{a}$ & $1716 \mathrm{ab}$ & $1680 \mathrm{a}$ \\
\hline Soil detritus & $232 \mathrm{~d}$ & $98 \mathrm{a}$ & $210 \mathrm{bcd}$ & $194 \mathrm{~b}$ \\
\hline
\end{tabular}


Tab. 3: Mean values of total and living below-ground net primary productivity (BNPP; maximum minus minimum values of total or living dry mass) and turn-over rate in wet submontane Cirsium meadow recorded during the growing season 1992.

\begin{tabular}{|c|c|c|c|c|}
\hline Fertilization & No & N0-PK & N90-PK & N180-PK \\
\hline Total BNPP (g.m- ${ }^{-2} \cdot \mathrm{yr}^{-1}$ ) & +129 & -47 & +351 & +113 \\
\hline Living BNPP $\left(\mathrm{g} \cdot \mathrm{m}^{-2} \cdot \mathrm{yr}^{-1}\right)$ & +316 & +228 & +435 & +259 \\
\hline Turn-over rate & 0.18 & 0.14 & 0.22 & 0.15 \\
\hline
\end{tabular}

(e.g. Hayes, Seastedt 1987, Hui, Jackson 2005, Fiala et al. 2012). However, the increased root accumulation in summer may be a function of changes in the length of the growing season, not of soil temperature (Fitter et al. 1998).

\section{Effect of fertilization}

In the summer (June 28), the fertilization mostly resulted in an increase of the total dry mass of below-ground plant parts at the third (N90-PK) and fourth (N180-PK) levels of fertilization particularly (Tab. 2). Increasing dry mass of below-ground parts was significantly most pronounced in stands loaded with the N90-PK fertilization in comparison with NO-PK treatment. Stands fertilized with $90 \mathrm{~kg}$ of $\mathrm{N}$ per ha reached the largest amount of dry mass of total rhizome, roots and total below-ground dry mass, i.e. 504, 1503 and 2008 g.m - $^{-2}$, respectively. However, data were rather variable. Although differences between data recorded in unfertilized and fertilized stands were not significant, trends of obtained numbers indicated that higher doses of fertilization were associated with increasing below-ground plant biomass. Data recorded in autumn (November 4) were more variable and mostly not significant.

Fertilization resulted in the greatest variability in the amount of soil detritus, i.e. decrease from 232 to 98 g.m ${ }^{-2}$ in unfertilized and the first level of fertilization (NO-PK) at the end of the growing season (Tab. 2). Increased intensity of fertilization and the effect of nitrogen doses particularly, generally resulted in the growth of above-ground plant parts rather than roots. Nevertheless overview of literature data summarized by several authors (e.g. Gáborčík, Kohoutek 1999, Fiala 2010) indicate that contradictory data on amount of root dry mass due to fertilization were often presented. Our obtained results confirmed our second assumption that fertilization supports production of below-ground plant parts. However, the marked increases in below-ground plant matter were still not recorded in meadows where the highest doses of fertilizers were applied. Nevertheless these findings of present authors are also supported by data of several authors (e.g. Lorenz 1977, Steen 1984, Gáborčík 1985, Li, Redman 1992) who reported, that TBDM decreased at the highest nitrogen level. In addition, similar findings arise from data of TBDM recorded by Hrabě et al. (2002) in the 1993-1998 years and fertilized submontane Cirsium meadow.

\section{Conclusions}

Data show how different roles can grasslands play in accumulation of plant matter due to different levels of fertilization. Obtained results demonstrate that different rate of fertilization can promptly and quickly increase both intensity of TBDM accumulation and BNPP values in the wet submontane Cirsium meadow. The greatest accumulation of TBDM was reached after application of $90 \mathrm{kgN} \cdot \mathrm{ha}^{-1}$. The highest BNPP values were calculated for the stand affected by the same amount of fertilization. But the highest doses of fertilizer applied (180 kgN.ha-1) showed an opposite trend, i.e. a reduction of root growth parameters. Estimated values of BNPP affected by fertilization represent valuable data, which were not still assessed for soil nutrient poor and wet Cirsium meadows.

\section{Acknowledgement}

This research was supported by national grants (GACR: 526/06/0556, MZeCR: QJ1220007) and with institutional support no. RVO: 67985939. This article is a product of the CzechGlobe Centre that is being developed within the OP RDI and co-financed from EU funds and the State Budget of the Czech Republic (CZ.1.05/1.1.00/02.0073). 


\section{References}

Balátová-Tuláčková, E., Tesařová, M., Zelená, V. 1977: Synökologische Charakteristik einiger wichtiger Wiesentypen des Naturschutzgebietes "Žd'árské vrchy". Rozpravy Československé akademie véd, 87: 1-115.

FialA, K. 1990: Live and dead underground plant biomass in a natural meadow hydrosere. Folia Geobotanica et Phytotaxonomica, 25: 113-135.

FiALA, K. 1997: Underground plant biomass of grassland communites in relation to mowing intensity. Acta Scientiarum naturalium Academiae scientiarum Bohemicae-Brno, 31: 1-54.

FialA, K. 2001: The role of root system of Calamagrostis epigejos in its successful expansion in alluvial meadows. Ekológia (Bratislava), 20: 292-300.

FialA, K. 2010: Belowground plant biomass of grassland ecosystems and its variation according to ecologiocal factors. Ekologia, 29: 182-206.

Fiala, K., ZÁhora, J., TƯma, I., Holub, P. 2004: Importance of plant matter accumulation, nitrogen uptake and utilization in expansion of tall grasses (Calamagrostis epigejos and Arrhenatherum elatius) into acidophilous dry grassland. Ekologia, 23: 225-240.

FiAlA, K., TŮmA, I., Holub, P. 2012: Interannual variation in root production in grasslands affected by artificially modified amount of rainfall. The Scientific World Journal, 2012: $1-10$.

Fitter, A.H., Graves, J.D., Self, G.K., Brown, T.K. 1998: Root production, turnover and respiration under two grassland types along an altitudinal gradient: influence of temperature and solar radiation. Oecologia, 114: 20-30.

FrANK, D.A. 2007: Drought effects on above and belowground production of grazed temperate grassland ecosystems. Oecologia, 152: 131-139.

GÁBORČíк, N. 1985: Štúdie produkčných procesov $v$ trávnych porastoch a možnosti ich regulácie z hl'adiska kvalitatívnej a kvantitatívnej produkcie. [The study of the production processes in a grassland stand and possibilities of its regulation from the point of view of qualitative and quantitative production]. PhD Thesis. Grassland Research Institute, Banská Bystrica.

Gaborčík, N., Коноutek, D. 1999: Reaction of root system of permanent and renovated grass swards on mineral fertilization. [Reakcia koreňového systému trvalých a ob- novených trávnych porastov na minerálne hnojenie]. Agrochémia, III (39): 4-6.

GiLl, R.A., Jackson, R.B. 2000: Global patterns of root turnover for terrestrial ecosystems. New Phytologist, 147: 13-31.

Gill, R.A., Kelly, R.H., PARTON, W.J. et al. 2002: Using simple environmetal variables to estimate belowground productivity in grasslands. Global Ecology and Biogeography Letters, 11: 79-86.

Gross, K.L., Peters, A., Pregitzer, K.S. 1993: Fine root growth and demographic responses to nutrient patches in four old-field plant species. Oecologia, 95: 61-64.

Hayes, D.C., Seastedt, T.R. 1987: Root dynamics of tallgrass prairie in wet and dry years. Canadien Journal of Botany, 65: 787-791.

Hrabě, F., Straka, J., Rosická, L. 2002: Produkční a strukturální změny polopřirozeného a nově setého lučního společenstva $\mathrm{v}$ oblasti CHKO Žd'árské vrchy. [Changes in the production and structure of seminatural and newly sown meadows community in the region of the Žd'árské vrchy (hills) protected landscape area]. In: KRAJčovič V. (ed): Ekológia trávného porastu VI, Výskumný ústav trávných porastov a horského polnohospodárstva, Banská Bystrica, 220-227.

Hui, D., Jackson, R.B. 2005: Geographical and interannual variability in biomass partitioning in grassland ecosystems: a synthesis of field data. New Phytologist, 169: 58-93.

Cheng, W., Coleman, D.C., Box, J.E. 1990: Root dynamics, production and distribution in agroecosystems on the Georgia Piedmont. Journal of Applied Ecology, 27: 592-604.

IUSS WorkING GROUP WRB. 2006: World reference base for soil resources 2006. 2nd edition. World Soil Resources Reports No. 103. FAO, Rome. ISBN 92-5-105511-4.

JAKRLOVÁ, J. 1971: Flooded meadow communities. An analysis of productivity in a dry year. Folia Geobotanica et Phytotaxonomica, 6: $1-27$.

Lauenroth, W.K., Wade, A.A., Williamson, M.A., Ross, B.E., Kumar, S., Cariveau, D.P. 2006: Uncertainty in calculations of net primary production for grassland. Ecosystems, 9: 843-851.

Lorenz, R. 1977: Changes in root weight and distribution in response to fertilization and harvest treatment of mixed prairie. In: MARSHALL, J.K. (ed.) The belowground ecosystem: A synthesis of plant-associated processes, Range Sci. Dep. Sci. Ser. No. 26, Colorado State Univ., Fort Collins, 63-71. 
Li, Y.S., Redman, R.E. 1992: Growth-responses to ammonium- $\mathrm{N}$, nitrate- $\mathrm{N}$ and defoliation in Agropyron-Dasystachyum from the Canadian mixed grassland. American Midland Naturalist, 127: 300-308.

MilchunAs, D.G. 2009: Estimating root production: Comparison of 11 methods in shortgrass steppe and review of biases. Ecosystems, 12: 1381-1402.

NI, J. 2004: Estimating net primary productivity of grasslands from field biomass measurements in temperate northern China. Plant Ecology, 174: 217-234.

Pandey, C.B., Singh, J.S. 1992: Rainfall and grazing effects on net primary productivity in a tropical savanna, India Ecology, 73: 2007-2021.

Pielota, M.N, Smucker, J.M. 1995: Fine root dynamics of alfa after multiple cuttings and during a late invasion by weeds. Agronomy Journal, 87:1161-1169.

PILÁt, A. 1969: Underground dry weight in the grassland communities of Arrhenathererum elatioris alopecuretosum pratensis R. Tx. 1937 and Mesobrometum erecti stipetosum Vicherek 1960. Folia Geobotanica et Phytotaxonomica, 4: 225-234.

Risch, A.C., Jurgensen, M.F., Frank, D.A. 2007: Effects of grazing and soil micro-climate on decomposition rates in a spatio-temporally heterogeneous grassland. Plant and Soil, 298: 191-201.

RYchNovsKÁ, M. 1983: Grasslands: A multifunctional link between natural and manmade ecosystems. Ekologia, 2: 337-345.

RychnovsKÁ, M. 1993: Temperate semi-natural grasslands of Eurasia. In: Coupland, R.T. (ed.) Ecosystems of the world. Grassland ecosystems, Amsterdam, Vol 2: 125-166.

Singh, J.S., Lauenroth, W.K., Hunt, H.W., Swift, D.M. 1984: Bias and random errors in estimators of net root production: a simulation approach. Ecology, 65: 1750-1764.

SPEIDEL, B. 1976: Primary production and root activity of a Golden Oat meadow with different fertilizer treatments. Polish Ecological Studies, 2: 77-89.
Stanton, N.L. 1988: The underground in grasslands. Annual Review Ecology and. Systematic, 19: 573-589.

Steen, E. 1984: Variation of root growth in a grass ley studied with a mesh bag technique. Swedish Journal of Agriculture Research, 14: 93-97.

Tesařová, M., Fiala, K., Studený, V. 1982: Live and dead roots - their mass ratio in several grassland stands. Folia Geobotanica et Phytotaxonomica, 17: 427-430.

TESAŘová, M. 1993: Micro-organisms in grasslands. In: RychnovsKÁ, M. (ed.): Structure and functioning of seminatural meadows. Academia, Praha, 245-277.

Titlyanova, A.A., Kosich, N.P., MironiczevaTokareva, N.P., Romanova, I.P. 1997: Underground plant organs of grassland ecosystems. Nauka, Novosibirsk.

Titlyanova, A.A., Romanova, I.P., Kosykh, N.P., Mironycheva-Tokareva, N.P. 1999: Pattern and process in above-ground and belowground components of grassland ecosystems. Journal of Vegetation Sciences, 10:307-320.

VeLICH, J. 1986: Studium vývoje produkčních schopností trvalých lučnich porostĩ a drnového procesu prí dlouhodobém hnojení a jeho optimalizace. [A study of the development of the production abilities of permanent grass stands and turf forming process and its optimalization under a long-term fertilization, in Czech]. University of Agriculture, Praha.

Vogt, K.A., Grier, C.C., Gower, S.T., Spruget, D.G., Vogt, D.J. 1986: Overestimation of net root production: a real or imaginary problem? Ecology, 67: 577-579.

Ward, K.J., Klepper, B., Rickman, R.W., AllmaRAS, R.R. 1978: Quantitative estimating of living wheat-root length in soil cores. Agronomy Journal, 70: 675-677.

Wedderburn, M.E., Crush, J.R., Pengelly, W.J., WALCROFt, J.L. 2010: Root growth patterns of perennial ryegrasses under well-watered and drought conditions. New Zealand Journal of Agricultural Research, 53: 377-388.

YahdJIAN, L., SAla, O.E. 2006: Vegetation structure constrains primary production response to water availability in the Patagonian steppe. Ecology, 87: 952-962. 
